\title{
Effect of Superblock Supplementation to Native Grass Based Diet on Rumen Fermentation In Vitro
}

\author{
Wahyono T, Hardani SNW, Firsoni \\ Agricultural Division, Center of Application for Isotope and Radiation, National Nuclear Energy Agency \\ Jl. Lebak Bulus Raya No. 49, Cilandak, South Jakarta 12070 \\ teguhwahyono@batan.go.id
}

\begin{abstract}
Superblock is the new generation of feed supplement which formulated from rice bran, molasses, soybean meal, urea, salt, and lacta-mineral. In vitro experiment was carried out to evaluate the effect of Superblock, supplemented in native grass based diet. Treatments evaluated were: $\mathrm{C}(60 \%$ native grass $+40 \%$ rice bran $)$ and $\mathrm{S}(\mathrm{C}+$ Superblock). Experimental design of this study was completely randomized design with two treatments and six replication. Gas production measurements were performed at $0,2,4,6,8,10,12,24$, and $48 \mathrm{~h}$. Methane and carbondioxide concentration were measured after $48 \mathrm{~h}$ incubation. In vitro organic matter digestibility (IVOMD), energy metabolism (EM) and total volatile fatty acids (TVFA) were calculated from the total gas production after $24 \mathrm{~h}$ incubation. Superblock supplementation in native grass based diet could increase optimum total gas production (13.37\%), IVOMD (8.45\%), EM (7.28\%), TVFA (10.41\%) and methane production $(4.67 \%)$. It was concluded that Superblock supplementation to native grass basal diet increased total gas production, IVOMD, EM and TVFA production. However, methane production also increased which is unwilling result therefore more appropiate strategy is needed to overcome this problem.
\end{abstract}

Key Words: In Vitro Study, Rumen Fermentation, Superblock, Total Gas

\section{INTRODUCTION}

The use of feed supplement in ruminant diet is one of the potential strategy to improve the animal production, because it can optimize the rumen ecosystem as a vital digestive tract in ruminant (Haryanto 2015). Feed supplement could be probiotics, natural antibiotics from herbs (Jouany \& Morgavi 2007) and the formulation from various feedstuffs. Many feed ingredients derived from agricultural and food by-products can be utilized in the feed supplement formulation. Roza et al. (2013) reported that there are many ways to produce feed supplement from by-product materials. However, the main principle of the supplement is to provide principal nutrient for microbial activity such as minerals, protein and soluble carbohydrates. Some study on feed supplement using by-product materials were reported by Roza et al. (2013), Wanapat \& Khampa (2006), Suharyono et al. (2014) and Firsoni \& Suharyono (2008). Indonesia national nuclear energy agency (BATAN) using tracer-radioisotope $\left({ }^{32} \mathrm{P}\right)$ technique previously reported that the formulation of agricultural and food by-products has resulted in feed supplement for ruminants. This supplements were urea molasses multinutrient block (UMMB), multinutrient feed supplement (MFS) and multinutrient feed supplement without molasses (MFSWM) (Suharyono 2009; Wahyono et al. 2010).

Superblock is the new generation of feed supplement which was formulated from agricultural and food by-product consisted of rice bran, molasses, soybean meal, urea, salt and lacta-mineral. In vitro experiment is needed to evaluate the effect of Superblock, supplementation in native grass based diet. In vitro gas test method has been selected for single feed screening and has a high correlation compared with in vivo methods (Menke et al. 1979; Getachew et al. 2000; Hamid et al. 2007). Therefore, the purpose of this study 
was to evaluate in vitro rumen fermentation product of native grass based diet suplemented with Superblock.

\section{MATERIAL AND METHODS}

\section{Samples preparation}

Native grass, rice bran and Superblock were dried at $60^{\circ} \mathrm{C}$ oven for three days and then ground to pass a fine particle size. Rumen fluid obtained from fistulated male buffalo fed a 60:40 concentrate:field grass. Buffalo was fed twice daily at 8.00 am and $4.00 \mathrm{pm}$. Rumen fluid was collected from middle part of the rumen.

\section{In vitro gas production}

The rumen strained and filtered through nylon net. The glassware infused with $\mathrm{CO}_{2}$ and kept at approximately $39^{\circ} \mathrm{C}$ before use. Amounts of $380 \mathrm{mg}$ DM samples were added with $40 \mathrm{ml}$ of rumen fluid-buffer in $100 \mathrm{ml}$ syringe (Fortuna model, Germany) by following the method of Menke et al. (1979) modification by Blümmel et al. (1997). The incubation was carried out in waterbath at $39^{\circ} \mathrm{C}$ for $48 \mathrm{~h}$. All of measurements were repeated six times. Gas production measurements were performed at $0,2,4,6,8,10,12$, 24 , and $48 \mathrm{~h}$. Methane and carbondioxide production were measured after $48 \mathrm{~h}$ incubation.

\section{Experimental methods and analysis}

Experimental design of this study was completely randomized design with two treatments and six replicates. All treatments descripted as follows: $\mathrm{C}$ (60\% field grass + $40 \%$ rice bran) and $\mathrm{S}(\mathrm{C}+3.42 \mathrm{mg}$ Superblock).

Variables measured were total gas production after $0,2,4,6,8,10,12,24$, and $48 \mathrm{~h}$ incubation. Methane and carbondioxide production after $48 \mathrm{~h}$ incubation were determined using MRU gas analyzer ${ }^{\circledR}$. Cumulative total gas production data were fitted to the model of Ørskov \& McDonald (1979) using software NEWAY ${ }^{\circledR}$ as follows:

$$
P=a+b\left(1-e^{-c t}\right)
$$

Where, $\mathrm{P}$ is the gas production at time $\mathrm{t}$, $\mathrm{a}$ is the gas production from soluble fraction $(\mathrm{ml} / 380 \mathrm{mg} \mathrm{DM}), \mathrm{b}$ is the gas production from insoluble fraction $(\mathrm{ml} / 380 \mathrm{mg} \mathrm{DM}), \mathrm{c}$ is the gas production rate constant $(\mathrm{ml} / \mathrm{h}),(\mathrm{a}+\mathrm{b})$ is the potential gas production $(\mathrm{m} / / 380 \mathrm{mg} \mathrm{DM})$ and $\mathrm{t}$ is the incubation time (h).

In vitro organic matter digestibility (IVOMD) and metabolisable energy (ME) were calculated by equation of Menke et al. (1979). Total volatile fatty acids (TVFA) were calculated by equation of Getachew et al. (2000):

$$
\begin{array}{ll}
\text { IVOMD }(\%) & =4.88+0.889 \mathrm{GP}+0.45 \mathrm{CP}+0.0651 \text { ash } \\
\text { ME }(\mathrm{MJ} / \mathrm{kg} \mathrm{DM}) & =2.20+0.136 \mathrm{GP}+0.057 \mathrm{CP} \\
\text { TVFA (mmol) } & =0.0239 \mathrm{GP}-0.0601
\end{array}
$$

GP was the nett gas production after $24 \mathrm{~h}$ incubation. $\mathrm{CP}$ and ash were crude protein and ash in g/100 g DM. ME and TVFA were converted to $\mathrm{kca} / \mathrm{kg} \mathrm{DM}$ and $\mathrm{mM}$. Effect of treatment was analyzed using SPSS 16.00 based the test of variance (ANOVA). 


\section{RESULTS AND DISCUSSION}

\section{Total gas production}

Total gas production from the fermentation of samples are presented in Table 1. Total gas production at $2,4,24$, and $48 \mathrm{~h}$ incubation time were highly significant $(\mathrm{P}<0.01)$. Total gas production at 6,10 , and $12 \mathrm{~h}$ incubation time were significant $(\mathrm{P}<0.05)$. However, Adding Superblock were not significantly increase total gas production at eight hours incubation. In present study, the increase pattern in total gas showed that Superblock could improve substrate digestibility in the early and late hours of incubations.

Table 1. In vitro total gas production of diet based fieldgrass

\begin{tabular}{lcrrrrrrr}
\hline \hline \multirow{2}{*}{ Treatment } & \multicolumn{7}{c}{ Incubation time (h) } \\
\cline { 2 - 9 } & 2 & \multicolumn{1}{c}{4} & \multicolumn{1}{c}{6} & \multicolumn{1}{c}{8} & \multicolumn{1}{c}{10} & \multicolumn{1}{c}{12} & \multicolumn{1}{c}{24} & \multicolumn{1}{c}{48} \\
\hline $\mathrm{C}$ & 6.420 & 11.980 & 17.870 & 24.720 & 29.070 & 36.640 & 51.680 & 61.620 \\
$\mathrm{~S}$ & 8.740 & 14.560 & 20.250 & 26.910 & 33.560 & 39.440 & 56.800 & 69.190 \\
SEM & 0.463 & 0.536 & 0.580 & 1.058 & 1.023 & 0.677 & 1.034 & 1.451 \\
\hline Significant & $* *$ & $* *$ & $*$ & NS & $*$ & $*$ & $* *$ & $* *$ \\
\hline
\end{tabular}

C: $60 \%$ field grass $+40 \%$ rice bran; S: C +3.42 mg Superblock; SEM: Standard error of mean; NS: Non-significant; *Significant at $\mathrm{P}<0.05 ; * *$ Significant at $\mathrm{P}<0.01$

Total gas production from in vitro fermentation reflects the extent of feed fermentation and digestibility (Getachew et al. 2000). In vitro total gas production increase by Superblock supplementation. This is caused by Superblock increase the microbes activity and feed degradability in rumen. Some of feed ingredients on Superblock is source of minerals, urea and molasses that can improve microbes activity. Minerals are required for microbial chemical reactions. Supplementation urea as soluble nitrogen in rumen ecosystem increase ammonia concentration $\left(\mathrm{NH}_{3}\right)$ which is required for microbial protein synthesis (Haryanto 2015). Molasses also has characteristics of rapidly fermented substrate, and high total gas production associate with sucrose concentration (Ferraro et al. 2009). This mechanism could increase degradability which are represented in total gas production. Fazaeli et al. (2012) reported that variations in gas production is the result of variations in chemical composition. The increase of total gas production not yet represented the efficiency of feed substrate utility. The feed efficiency could be observed from variable of gas characteristics (Table 2).

Table 2. In vitro gas characteristics of diet based field grass after $48 \mathrm{~h}$ incubation

\begin{tabular}{|c|c|c|c|c|}
\hline \multirow{2}{*}{ Treatment } & \multicolumn{2}{|c|}{ Treatment } & \multirow{2}{*}{ SEM } & \multirow{2}{*}{ Significan } \\
\hline & $\mathrm{C}$ & $S$ & & \\
\hline$a+b(\mathrm{ml} / 380 \mathrm{mg} D M)$ & 64.60 & 73.24 & 1.697 & $* *$ \\
\hline $\mathrm{c}(\mathrm{ml} / \mathrm{h})$ & 0.069 & 0.063 & 0.002 & NS \\
\hline $\mathrm{CH}_{4}(\%)$ & 14.75 & 14.84 & 0.067 & NS \\
\hline $\mathrm{CO}_{2}(\%)$ & 58.21 & 59.34 & 1.092 & NS \\
\hline $\mathrm{CH}_{4}(\mathrm{ml} / \mathrm{IVOMD})$ & 4.92 & 5.15 & 0.053 & $*$ \\
\hline $\mathrm{CO}_{2}(\mathrm{ml} / \mathrm{IVOMD})$ & 19.43 & 20.58 & 0.393 & NS \\
\hline $\mathrm{CO}_{2}: \mathrm{CH}_{4}$ & 3.95 & 4.00 & 0.081 & NS \\
\hline
\end{tabular}

C: $60 \%$ field grass $+40 \%$ rice bran; $\mathrm{S}: \mathrm{C}+3.42 \mathrm{mg}$ Superblock; a+b: Potential gas production; c: Gas production rate; DM: Dry matter; IVOMD: In vitro organic matter digestibility; SEM: Standard error of mean; NS: Non-significant; *Significant at $\mathrm{P}<0.05$; $* *$ Significant at $\mathrm{P}<0.01$ 


\section{In vitro gas characteristics}

In vitro gas characteristics shown in Table 1 . The potential total gas production $(\mathrm{a}+\mathrm{b})$ of $\mathrm{S}$ treatment was significantly $13.37 \%$ higher than $\mathrm{C}$ treatment $(\mathrm{P}<0.01)$. However, $\mathrm{CH}_{4}$ production (ml/IVOMD) of $\mathrm{S}$ treatment also higher than $\mathrm{C}$ treatment $(\mathrm{P}<0.05)$. There is no significant difference between $\mathrm{C}$ and $\mathrm{S}$ treatment in gas production rate (c), $\mathrm{CH}_{4}$ concentration (\%), $\mathrm{CO}_{2}$ concentration $(\%), \mathrm{CO}_{2}$ production (ml/IVOMD) and $\mathrm{CO}_{2}: \mathrm{CH}_{4}$ rate. Sofyan et al. (2015) reported that fermentation evaluation by in vitro gas production indicated with kinetics gas parameters. Higher value of potential gas production in $S$ treatment indicated that superblock can increase the microbial activity in the rumen.

The increase of microbial activity followed by increasing in protozoa growth population. It could be seen from the higher value of methane production in $\mathrm{S}$ treatment. Some of feed ingredients on superblock is molasses and minerals. Molasses ingredient in supplement may increase protozoa population (Suharyono et al. 2010). Suharyono \& Widiawati (2007) also reported that molasses is easily digested carbohydrates which are major feed for protozoa. Bhatta et al. (2015) also reported that methane production was related to the protozoa population. Methane was generated by methanogens bacteria that consumed hydrogen. Supplementation of $3.42 \mathrm{mg}$ superblock increase methane production and indicated the low efficiency of energy use of feed by microbial activity. Energy lost was represented by high methane emission. This present study contradiction to Se-Young et al. (2011) that using glycerol as supplement decreased methane production and increased substrate efficiency. Prasetiyono et al. (2007) also reported that supplementation of protein supplement (SPN) in rice straw and bran based ration can decrease methane production. This difference perhaps due to the differences of ingredients in each supplement, which superblock contains molasses that can increase easily digested substrate for protozoa.

\section{Rumen fermentation products}

Calculation of in vitro rumen fermentation products of diet based fieldgrass are presented in Table 3. The IVOMD, EM and TVFA results were higher in $\mathrm{S}$ treatments than $\mathrm{C}$ treatment $(\mathrm{P}<0.01)$. The increase of IVOMD, EM and TVFA were a representation from in vitro total gas production after superblock supplemented (Table 1). Minerals, urea and molasses that contained in superblock can support microbial growth and improve fermentation activity.

Table 3. Calculated in vitro rumen fermentation product of diet based fieldgrass

\begin{tabular}{lccc}
\hline \hline Treatment & IVOMD (\%) & EM (kcal/kg DM) & TVFA (mM) \\
\hline C (60\% field grass + 40\% rice bran) & 55.29 & 2322.29 & 29.38 \\
S (C + 3.42 mg Superblock) & 59.96 & 2491.39 & 32.44 \\
SEM & 0.932 & 33.902 & 0.618 \\
\hline Significant & $* *$ & $* *$ & $* *$ \\
\hline
\end{tabular}

IVOMD: In vitro organic matter digestibility; EM: Energy metabolisable; TVFA: Total volatile fatty acid; SEM: Standard error of mean; **Significant at $\mathrm{P}<0.01$

The production of TVFA in present study was 29.38 and $32.44 \mathrm{mM}$. This value was lower than the range of TVFA production in rumen. The range of TVFA in the rumen are 50-100 mM (forages fed) and 80-150 mM (concentrate fed) (Owen \& Goetsch 1988; 
Jayanegara \& Sofyan 2008). The lower value in TVFA production from present study due to the conditions of closed fermentation system. It could be give negative effect for microbial activity (Jayanegara \& Sofyan 2008). The lower TVFA value is a reflection from the changes of rumen microbial population (Pamungkas et al. 2006). The increasing IVOMD after Superblock supplementation will be followed with the increasing of EM. This is caused by the improved of balance microbial activity in rumen ecosystem as Superblock contained molasses as higher fermentable carbohydrates and urea as available nitrogen source. The higher fermentable carbohydrates and available nitrogen source make a better nutrient availability for rumen microbial activity that represented in IVOMD and ME (Ahmed et al. 2007).

\section{CONCLUSION}

Supplementation of superblock increase total gas production, IVOMD, EM and TVFA production from diet based field grass. However, methane production also increased, so there is still need more appropriate strategy to overcome this problem.

\section{ACKNOWLEDGEMENT}

The author wish to thank Imra Atul Uswah, Elsa Lestari and all members in Animal Nutrition Laboratory. Gratitude is also expressed to Mr. Dedi Ansori and others who helped in the field during this project.

\section{REFERENCES}

Ahmed GM, Abdel NMAFE. 2007. Chemical composition and in vitro gas production characteristics of six fodder trees, leaves and seeds. Res J Agric Bio Sci. 3:983-986.

Bhatta R, Saravanan MM, Baruah L, Prasad CS. 2015. Effect of graded level of tannin-containing tropical tree leaves on in vitro rumen fermentation, total protozoa and methane production. $\mathrm{J}$ Appl Microbiol. 118:557-564.

Blümmel M, Steingass H, Becker K. 1997. The relationship berween in vitro gas production, in vitro microbial biomass yield and ${ }^{15} \mathrm{~N}$ incorporated and its implication for the prediction of voluntary feed intake of roughages. Br J Nutr. 77:911-921.

Fazaeli H, Golmohammadi HA, Tabatabayee SN, Asghari-Tarbrizi M. 2012. Productivity and nutritive value of barley green fodder yield in hydroponic system. World App Sci J. 16:531539.

Ferraro SM, Mendoza GD, Miranda LA, Guitiêrrez. 2009. In vitro gas production and ruminal fermentation of glycerol, propylene glycol and molasses: Short communication. Anim Feed Sci Tech. 154:112-118.

Firsoni, Suharyono. 2008. Pengaruh suplemen pakan multinutrien (SPM) terhadap pertambahan bobot badan domba secara in vivo. Dalam: Dengan Semangat 50 Tahun BATAN Kita Mantapkan Peran Aplikasi Teknologi Isotop dan Radiasi untuk Kesejahteraan Masyarakat. Prosiding Simposium dan Pameran Teknologi Aplikasi Isotop dan Radiasi. Jakarta 5-6 Agustus 2008. Jakarta (Indonesia): Badan Tenaga Nuklir Nasional, Pusat Aplikasi Teknologi Isotop dan Radiasi. p. 245-248.

Getachew G, Makkar HPS, Becker K. 2000. Effect of polyethilene glycol on in vitro degradability and microbial protein synthesis from tannin-rich browse and herbaceous legumes. B J Nutr. 84:73-83. 
Hamid P, Akbar T, Hossein J, Ali MG. 2007. Nutrient digestibility and gas production of some tropical feeds used in ruminant diets estimated by the in vivo and in vitro gas production techniques. Am J Anim Vet Sci. 2: 108-113.

Haryanto, B. 2015. Technology in feeding management to increase ruminant productivity. Wartazoa 25:197-205.

Jayanegara A, Sofyan A. 2008. Penentuan aktivitas biologis tanin beberapa hijauan secara in vitro menggunakan 'Hohenheim gas test' dengan polietilen glikol sebagai determinan. Media Peternakan 31:44-52.

Jouany JP, Morgavi DP. 2007. Use of 'natural' products as alternatives to antibiotic feed additives in ruminant production. Animal. 1:1443-1466.

Menke KH, Raab L, Salewski A, Steingass H, Fritz, Schneider W. 1979. The estimation of the digestibility and metabolizable energy content of ruminant feeding stuffs from the gas production when they are incubated with rumen liquor. J Agric Sci. 93:217-222.

Ørskov ER, Mcdonald I. 1979. The estimation of protein degradability in the rumen from incubation measurements weighted according to the rate of passage. J Agr Sci Camb. 92:499503.

Owens FN, Goetsch AL. 1988. Ruminal fermentation. In: Church DC, editor. The ruminant animal digestive physiology and nutrition. New Jersey (US): Pretince Hall, Englewood Cliffs.

Pamungkas D, Sevilla CC, Lustria UM. 2006. Changes in rumen ecosystem and feed dry matter degradability of buffalo which received rumen content of cattle through cross inoculation. JITV. 11:24-33.

Prasetiyono BWHE, Suryahadi, Torahmat T, Syarief R. 2007. Strategi suplementasi protein ransum sapi potong berbasis jerami dan dedak padi. Media Peternakan. 30:207-217.

Roza E, Suardi MS, Nurdin E, Aritonang SN. 2013. Digestibility test of cassava leaves in feed supplement on buffaloes by in vitro. Pak J Nutr. 12:505-509.

Se-Young L, Sang-Moon L, Yong-Bae C, Dong-Keun K, Sang-Cheol L, Chang-Hyun K, Seongwon S. 2011. Glycerol as a feed supplement for ruminants: In vitro fermentation characteristics and methane production. Anim Feed Sci Tech. 166-167:269-274.

Sofyan A, Sakti AA, Karimy MF, Julendra H, Istiqomah L, Herdian H, Damayanti E, Suryani AE. 2015. Effectivity of probiotic, micromineral enriched yeast and their combination with Azadirachta indica leaves containing tannin on fermentability and digestibility of Pennisetum hybrid. JITV. 20:95-104.

Suharyono, Firsoni, Widiawati Y. 2010. Pengaruh pemberian suplemen pakan multinutrien (SPM) tanpa molasses terhadap ekosistem rumen dan produktivitas domba. Dalam: Prasetyo LH, Natalia L, Iskandar S, Puastuti P, Herawati T, Nurhayati, Anggraeni A, Damayanti R, Dharmayanti NLPI, Estuningsih SE, penyunting. Teknologi Peternakan dan Veteriner Ramah Lingkungan dalam Mendukung Program Swasembada Daging dan Peningkatan Ketahanan Pangan. Prosiding Seminar Nasional Teknologi Peternakan dan Veteriner. Bogor, 3-4 Agustus 2010. Bogor (Indonesia): Puslitbangnak. hlm. 530-536.

Suharyono, Widiawati Y. 2007. Ekosistem rumen sapi PO yang diberi pakan suplemen multinutrien (SPM) atau legor. Dalam: Darmono, Wina E, Nurhayati, Sani Y, Prasetyo LH, Triwulanningsih E, Sendow I, Natalia L, Priyanto D, Indraningsih, Herawati T, penyunting. Akselerasi Agribisnis Peternakan Nasional melalui Pengembangan dan Penerapan IPTEK. Prosiding Seminar Nasional Teknologi Peternakan dan Veteriner. Bogor, 21-22 Agustus 2007. Bogor (Indonesia): Puslitbangnak. hlm. 71-76.

Suharyono. 2009. Pengembangan suplemen pakan untuk ternak ruminansia dan pengenalannya kepada peternak. Presentasi Ilmiah. Jakarta, 16 Februari 2009. Jakarta (Indonesia): Pusat Aplikasi Isotop dan Radiasi, Badan Tenaga Nuklir Nasional. 
Suharyono, Sutanto H, Purwanti Y, Martanti, Agus A, Utomo R. 2014. The effect of urea molasses multi-nutrient block and medicated multi-nutrient block for beef and dairy cattle. Atom Indonesia. 40:77-87.

Wahyono T, Kusumaningrum CE, Suharyono. 2010. Pengaruh pemberian suplemen pakan multinutrien tanpa molases terhadap pertambahan berat badan harian sapi potong dara. Dalam: Prosiding dalam simposium dan pameran teknologi aplikasi isotop dan radiasi. Jakarta, 27-28 Oktober 2010. Jakarta (Indonesia): Pusat Aplikasi Isotop dan Radiasi, Badan Tenaga Nuklir Nasional. hlm. 381-387.

Wanapat M, Khampa S. 2006. Effect of cassava hay in high-quality feed block as anthelminthics in steers grazing on ruzi grass. Asian-Australas J Anim Sci. 19:695-698. 